\title{
Autos de Rei Congo em Fortaleza: Uma prática cultural negra na dinâmica socioespacial da cidade (1873-1900)
}

\author{
Janote Pires Marques ${ }^{1}$
}

\begin{abstract}
Resumo: Nas últimas décadas do século XIX, Fortaleza passou por grandes transformações urbanas, sociais e políticas. Nesse contexto, as manifestações culturais festivas negras que ocorriam na cidade sofreram perseguições e tentativas de controle. Para resistir, essa cultura negra recriava-se a partir das vivências de seus sujeitos. Esse artigo analisa o deslocamento dos reis negros coroados na Irmandade do Rosário de Fortaleza para outras manifestações culturais, como os autos de rei congo. Ressaltam-se diversas dimensões presentes nessas festas, ampliando, portanto, a visão de que eram apenas diversões e buscando percebê-las também como espaços de sociabilidades e de reelaborações culturais, bem como instrumentos dos negros para a conquista de territórios físicos e simbólicos na cidade.
\end{abstract}

Palavras-chave: festas de negros, Congos, Irmandade do Rosário, sociabilidades.

Abstract: In the last decades of the nineteenth century, Fortress has gone through major transformations, urban and social policies. In this context, the black cultural festival taking place in the city have suffered persecution and attempts at retrenchment. To resist, that black culture is recreated from the experiences of individuals who worked at these parties. This article examines the displacement of black kings crowned in the Brotherhood of the Rosary of Fortaleza to other cultural events, such as records of King Congo. We highlight several dimensions in those parties, extending therefore the view that they were just looking for fun and perceive them as well as spaces of sociability and cultural reworkings, as well as powerful instruments of blacks to conquer territories in the physical and symbolic city.

Key-words: black parties, Congos, Brotherhood of the Rosary, sociability.

Anuncios - Congos
Alerta rapasiada!
Cabeças falantes!
- Raymundo Gurgulho -
A voz de trovão
Joaquim Xavier
Nas furias de imperador (...)
Promete a maior novidade.
Preços e horas do costume.

O anúncio acima foi publicado em 1890, divulgando uma apresentação de "Congos" em Fortaleza. Por esse tempo, os Congos eram encenados em praças e terrenos baldios da cidade, constituindo autos (encenações) sobre antigas guerras congo-angolanas. O Rei do Congo, o Príncipe Sueno e o Embaixador da Rainha Ginga eram personagens principais, sendo os intérpretes desses papeis (re)conhecidos na cidade. Havia, ainda, a participação de vários outros sujeitos, como os componentes do coro, os músicos, os

\footnotetext{
1 Mestre em História Social pela Universidade Federal do Ceará (UFC). Membro do Grupo de Estudos “Trabalhadores Livres e Escravos no Ceará", sediado no Departamento de História da UFC. Professor de História, no Colégio Militar de Fortaleza. Autor do livro Festas de negros em Fortaleza. Territórios, sociabilidades e reelaborações (1871-1900). Fortaleza: Expressão Gráfica, 2009.

2 Biblioteca Pública Governador Menezes Pimentel (BPGMP), Núcleo de Microfilmagem. Jornal Cearense. Fortaleza, 8 jan. 1890. p. 2, rolo no 35 .
} 
figurantes e mesmo as pessoas que assistiam às apresentações. Todos, de alguma forma, interagiam naquela manifestação cultural de raízes africanas.

Com efeito, os Congos eram espaços para constantes (re)elaborações de práticas culturais negras a partir das experiências de vida dos sujeitos participantes desses grupos. Nesse sentido, a proposta desse artigo é refletir sobre o que eram os autos de Rei Congo em Fortaleza, nos quais se cantava uma "tradição bélica" africana, mas, também, relacionamentos amorosos, atividades de trabalho, críticas sociais, o dia-a-dia, enfim, da sociedade na qual os Congos estavam inseridos.

Além disso, são considerados aspectos que permeavam a vida na Fortaleza de fins do XIX e que fomentavam o controle sobre determinadas práticas culturais. Nesse sentido, destaco o processo de "romanização" do clero, as ideias de "civilização" e de "progresso", o projeto de "modernização" de Fortaleza, incluindo-se o plano urbanístico de 1875 (elaborado por Adolfo Herbster), numa tentativa do poder público em sistematizar a expansão da cidade através do alinhamento de ruas e da abertura de novas avenidas.

Nessa cidade em movimento, os Congos foram obrigados a lugares cercados, sendo suas apresentações nos locais de "costume", como a Praça dos Coelhos (atual Praça José Bonifácio), Praça de Pelotas (atual Praça Clóvis Beviláqua) e Praça do Livramento (atual Praça do Carmo). Entretanto, eram espaços públicos que os Congos transformavam em territórios de uma cultura negra, ainda que por algumas semanas no ano.

É nesse contexto, denominado aqui de "socioespacial", que os Congos se apresentavam, permitindo-se, até por uma questão de sobrevivência (e de resistência), um constante reelaborar-se. Ao mesmo tempo, apropriavam-se de espaços, como as praças, conquistando certas territorialidades na cidade. ${ }^{3}$

Partindo das considerações feitas e dessa dinâmica social e urbana na qual os Congos atuavam, procurarei, então, analisar o que era essa prática cultural (negra), bem como tecer uma relação entre seus sujeitos e a ocupação de espaços públicos (ruas e praças) e privados (terrenos baldios) da cidade.

\section{Os Congos e a Irmandade do Rosário de Fortaleza}

Apresentações públicas dos Congos ocorriam em Fortaleza desde a época em que ainda existiam reis e rainhas negros na Irmandade de Nossa Senhora do Rosário dos

\footnotetext{
3 A ideia de "territorialidade" aparece aqui de acordo com SILVA, Elizete Américo e SOUZA, Maria Salete de. Espaços públicos e territorialidades no centro de Fortaleza; e SILVA, José Borzacchiello da. Fortaleza, a metrópole sertaneja do litoral. In: SILVA, José Borzacchiello da, etc. Litoral e Sertão, natureza e sociedade no nordeste brasileiro. Fortaleza: Expressão Gráfica, 2006.
} 
Homens Pretos da Capital, e muitas vezes o Rei Congo e o Rei do Rosário eram a mesma pessoa. Antes da apresentação era preciso que o "diretor" do Congo se dirigisse à cadeia pública e solicitasse por escrito através do "Livro da Porta da Cadeia" a autorização para apresentar-se. O delegado analisava o pedido, que geralmente era deferido, devendo, no entanto, o responsável pelo "folguedo" pagar uma taxa, após a qual recebia uma autorização manuscrita com as datas previstas para a apresentação.

Veja-se a seguir um exemplo dessa solicitação.

Benedicto Antonio de Moraes requerendo licencia para aprezentar em publico o folguedo $=$ Congo $=$ desde o dia 24 deste até o dia 20 de Janeiro vindouro.

Despacho.

Pagos direitos fiscaes volte. ${ }^{4}$

Por esse tempo, ainda não havia maiores restrições quanto aos locais de apresentação, desde que se pagassem as taxas e fosse autorizado pela polícia. Geralmente, os Congos dançavam em frente à Igreja do Rosário de Fortaleza e depois se dirigiam a determinadas casas de famílias, nas quais tinham oportunidade de representar reminiscências da história africana, mas, também, de receber em troca alimentos, bebidas e mesmo algum dinheiro. ${ }^{5}$

Por outro lado, a festa de coroação de reis negros (Congos) dentro da Igreja do Rosário era vista como “desvio" das práticas católicas, o que levou à retirada dos cargos de rei e rainha na Irmandade do Rosário da Capital, durante a reformulação do compromisso de 1840 e sua consequente substituição pelo de $1873 .{ }^{6}$

Tem-se aqui um reflexo do enfraquecimento da Irmandade de "Homens Pretos" em Fortaleza e, ao que parece, um fator importante que contribuiu para isso foi uma crítica sistemática da Igreja às práticas religiosas das confrarias, que representavam, vale lembrar, um catolicismo leigo mas, também, oficial, já que as Irmandades funcionam seguindo estatutos transformados em leis provinciais.

\footnotetext{
4 Arquivo Público do Estado do Ceará (APEC), Fundo Secretaria de Polícia do Ceará. Lançamento de requerimentos e despachos. 23 mar. 1868. Livro 02, fl 14 v. (A Cadeia Pública ficava onde hoje é o Centro de Artesanato de Fortaleza)

${ }^{5}$ NOGUEIRA, João. Fortalez̧a velha: crônicas. 2. ed. Fortaleza: Edições UFC/PMF, 1980, p. 3.

${ }^{6}$ Resolução n 209, de $1^{\circ}$ de Setembro de 1840 (Compromisso da Irmandade de Nossa Senhora do Rosario dos Homens Pretos de Fortaleza). In: BARROSO, José Liberato. Compilação das Leis Provinciais do Ceará. Rio de Janeiro: Typographia Universal Laemment, 1863; e Resolução nº. 1538, de 23 de agosto de 1873 (Compromisso da Irmandade de Nossa Senhora do Rosario da Capital). In: Colleção de actos legislativos da Provincia do Ceará promulgados pela respectiva Assemblèa no anno de 1873. Fortaleza: Typographia Constitucional, 1874.
} 
Esse "processo de romanização", política empreendida pela elite eclesiástica imperial tentando reformar a vida religiosa católica, afetou o catolicismo praticado por descendentes de africanos. De acordo com o pensamento católico conservador ${ }^{8}$, o comportamento dos irmãos fora da Igreja do Rosário também poderia ser reprovável.

Rodolfo Theophilo, lembrando-se do tempo em que assistia à missa dominical na Igreja do Rosário de Fortaleza, relata que no dia 6 de janeiro - Dia de Reis - havia missa com a presença do rei, rainha e sua corte.

O rei era um preto já idoso, de manto, sceptro e corôa. A rainha, uma escrava, meio velha, acompanhada de duas damas de honor. Na Capela-mór estava armado o throno, em que se deviam sentar suas majestades. Logo que chegava o rei com sua corte, entrava a missa, que era cantada, com repiques de sinos e foguetes. (...) Acabada a missa, sahia o cortejo real de cidade a fóra até o palacio, em que passava o resto do dia a comer, beber, a dansar, festejando as poucas horas de liberdade que todos os annos lhe concediam os senhores da terra que primeiro libertou os seus escravos. ${ }^{9}$

$\mathrm{Na}$ festa de coração o negro era rei não somente de um espaço mas também de uma espécie de território cultural; recebia reverências e era a referência, no sentido de que para ele e sua corte real é que se voltavam os olhares, seja dos "súditos" da irmandade, seja da gente da cidade.

Ora, se os negros acompanhavam a missa e a festa de coroação, era mais porque ali se constituía espaço para encontro de gente voltada a práticas culturais festivas de raízes africanas, como os Congos. Daí muitos negros se fazerem presentes ao evento, pois, ainda que não pertencessem à Irmandade, poderiam assistir à coroação de um companheiro que também era "Rei Congo", muitas vezes o "dono" de um dos "folguedos" de mesmo nome, que se apresentavam em praças e terrenos baldios da cidade, representando cenas da história africana.

Em geral os negros donos de congos eram conhecidos na cidade e isso podia ajudar na sua eleição para rei da Irmandade, considerando sua capacidade de agregar pessoas,

\footnotetext{
7 "Processo de romanização" aparece aqui no sentido de ser um movimento reformador que pretendia tornar o catolicismo no Brasil mais ligado às diretrizes de Roma, ou seja, da autoridade do papa; envolvendo um crescente número de bispos em defesa de uma maior autonomia do poder espiritual perante as autoridades imperiais e o poder dos leigos reunidos em irmandades. "Requereu um grande investimento na formação moral e intelectual do clero, que substituiria o antigo, liberal e regalista e tido como despreparado, para, através dele, formar católicos no modelo da Igreja tridentina (seguindo as determinações do antigo Concílio de Trento, 1543-63)”. Cf. VAINFAS, Ronaldo (Org.). Dicionário do Brasil imperial. Rio de Janeiro: Objetiva, 2002, p. 660-661.

8 Também conhecido como "ultramontanismo", teve no Seminário da Prainha, em Fortaleza, a partir de 1964, seu grande foco irradiador no Ceará. Cf. MONTENEGRO, João Alfredo de Sousa. O trono e o altar. As vicissitudes do tradicionalismo no Ceará (1817-1978). Fortaleza: BNB, 1992, p. 94.

9 THEOPHILO, Rodolfo. Scenas e Typos. Fortaleza: Typ. Minerva, 1919, p. 35-36.
} 
arrecadar contribuições, ter contato com autoridades - ainda que fosse o delegado para quem solicitava autorização para suas apresentações.

Por isso tudo, era inaceitável, sob a ótica conservadora católica, uma missa com a presença de reis negros - encenando uma figura monárquica africana -, seguida de um barulhento cortejo da realeza negra pelas ruas da cidade, indo para uma casa (palácio) onde aconteceria uma festa (comida, bebida, música e danças de matrizes africanas).

Outro aspecto ligado à "romanização" e que certamente contribuiu para o enfraquecimento das confrarias em Fortaleza foi o apoio dado pela Igreja às Conferências Vicentinas, associações religiosas organizadas de acordo com as diretrizes dos padres lazaristas franceses e que, de certa forma, atuaram substituindo as irmandades no trabalho social em várias áreas: saúde, solidariedade, apoio a enterramentos.

Geralmente compostas por grupos pequenos e atuantes, a partir da década de 1880 as Conferências Vicentinas atuaram intensamente na Capital ${ }^{10}$ do Ceará, em parte por conta da aproximação com setores da elite intelectual. ${ }^{11}$

Ao mesmo tempo em que se desenvolvia o trabalho social voluntário vicentino, crescia a dificuldade dos irmãos na arrecadação de esmolas (vistas como práticas indesejadas no espaço público) para atos das Irmandades em Fortaleza; a do Rosário - não podendo mais contar com os reis negros que conseguiam levantar esmolas mais facilmente - teve suas rendas diminuídas. Em 1881, na tentativa de limitar a coleta de esmolas em Fortaleza, o bispo D. Luís Antônio dos Santos determinou o seguinte:

\footnotetext{
Não se deve ser tolerado o abuso que se vem introduzindo nesta Capital de julgar-se qualquer devoto autorizado a pedir esmolas pelas ruas, figurando-se pertencer a confrarias que não existem, chamo a atenção do Reverendo Cura da Sé que só permita que em sua freguesia, peçam esmolas revestidos de opas e usando de bolsas individuos que pertençam a confrarias cujos compromissos foram aprovados canonicamente, não podendo ter cada irmandade mais de uma bolsa percorrendo as ruas nos limites de sua freguesia. ${ }^{12}$
}

\footnotetext{
${ }^{10}$ Em Fortaleza foram fundadas as seguintes conferência de São Vicente de Paulo: no ano de 1882, fundou-se uma conferência vicentina (a primeira) em Fortaleza, sob a invocação de São José. A seguir, outras foram criadas: em 1883, sob a invocação de São Luiz; em 1884, sob a invocação de Nossa Senhora do Carmo; em 1885, surgiram várias sob as invocações do Sagrado Coração de Jesus, de São Benedito, do Santíssimo Coração de Maria, da Imaculada Conceição; em 1887, sob a invocação de São Tomás de Aquino; no ano de 1888, sob a invocação de São Leão. Cf. STUDART, Guilerme. Datas e factos para a História do Ceará. op. cit., p. 294, 308, 331, 336, 337, 354, 355.

${ }^{11}$ Foi o caso da fundação da "Conferencia de S. Vicente de Paulo sob a invocação do Sagrado Coração de Jesus. (...) Tendo tido por presidentes o Dr. Guilherme Studart (1885), Antônio Bezerra de Menezes (1888) e o Dr. Antônio Epaminondas da Frota (1889), STUDART, Guilherme. Datas e factos para a História do Ceará. op. cit., p, 336.

${ }^{12}$ Sala de História Eclesiástica da Arquidiocese de Fortaleza (SHEAF). Fundo Registro de Provisões. Oficios diversos do bispo as autoridades diocesanas. 27 ago. 1881. Livro 137, fl. 39.
} 
Uma das implicações dessa inibição das esmolas como fonte de recursos, foi a insconstância nas missas de Natal no Rosário e até mesmo a suspensão delas. É o que transparece na atitude do "capellão" da Igreja do Rosário de Fortaleza, em meados da década de 1880.

\begin{abstract}
Missa do Rosario
Previne-se aos devotos desta capital, que não havera missa de natal na egreja do Rosario, por que so poderia haver correndo a bolsa ás esmolas, como sempre se fez, pois foi prohibido pelo delegado e o Sr. Bispo, a pedido do capellão Macahyba, que deixa dizer a missa de sua obrigação para dizer no Allagadiço, como é de costume pois há quatro annos e capellão e ainda não celebrou uma só missa de natal como os outros capellões. E agora sucede que sendo o padre Macahyba capellão da marinha e do Rosario, não se sabe qual sua obrigação, por isso pedese-lhe que se explique para com o publico. Um irmão. ${ }^{13}$
\end{abstract}

Mesmo com o enfraquecimento da Confraria e, por conseguinte, com a diminuição do número de irmãos e, também, sofrendo o controle eclesiástico conservador e praticamente sem poder coletar esmolas, a Irmandade do Rosário de Fortaleza ainda possuía instalações, prédios para foros (aluguéis) e terrenos que, com o crescimento urbanístico da Capital cearense nas décadas finais do XIX, passaram a ser cada vez mais valorizados.

Por outro lado, isso acabaria levando ao envolvimento da Confraria em várias contendas a fim de conservar tais bens. Foi o caso da disputa deflagrada em outubro de 1890, quando o comendador Francisco Coelho da Fonseca, pretendendo anexar algumas propriedades da Irmandade do Rosário, solicitou ao Juízo da Provedoria ${ }^{14}$ a nomeação de um procurador para representar a Confraria no litígio. Suspeitosamente foi escolhido como procurador Francisco Nunes, empregado de uma casa comercial pertencente ao genro do comendador Coelho.

Patrimonio de N. Senhora do Rosario

Já é conhecida a demarcação por meio da qual o comendador Francisco Coelho conseguiu fazer um excellente acordo com a Santa sendo ella em tudo representada pelo Sr. Francisco, empregado da casa commercial do Sr. Luiz Cunha, genro do comendador Coelho, como se tem lido no Libertador. O negocio foi o melhor possivel porque as terras são as mais desejadas e $\mathrm{N}$. Senhora do Rosario pode perder ou diminuir seu patrimonio. (...). ${ }^{15}$

\footnotetext{
${ }^{13}$ BPGMP, Núcleo de Microfilmagem. Jornal Libertador. Fortaleza, 23 dez. 1887, p. 3, rolo no 202.

${ }^{14}$ Era o órgão responsável pela tomada de prestação de contas que deveriam ser feitas pelos tesoureiros das irmandades. Com o advento da República (Decreto n. 119-A, de 7 jan. 1890), as irmandades não mais precisavam da autorização do Governo para funcionar, passando a responder diretamente aos bispos - "tanto no espiritual como no temporal" - das respectivas localidades onde essas confrarias estavam instaladas. A função do juiz da provedoria passou ser apenas o simples registro dessas irmandades. BPGMP, Núcleo de microfilmagem. Jornal A Verdade. Fortaleza, 5 out. 1890, p. 5, rolo nº 90.

${ }^{15}$ BPGMP, Núcleo de Microfilmagem. Jornal Libertador. Fortaleza, 08 out. 1890, p. 3, rolo nº 203.
} 
Depois de intenso pleito, a Irmandade do Rosário teve seu patrimônio lesado, perdendo, ainda, alguns foros. Percebe-se, portanto, que foram diversos os fatores que levaram ao enfraquecimento da irmandade de negros existente na Igreja do Rosário de Fortaleza. Além disso, esses tipos de confrarias foram-se tornando cada vez menos organizações exclusivas de negros, que aos poucos passavam a ocupar outros espaços de sociabilidades.

Quanto à festa de coroação de reis negros (Congos) na Irmandade, é preciso considerar que a essência do evento se colocava em relevo fora da igreja, pois o interesse da maioria dos participantes estava na festa e mesmo nos preparativos que a coroação envolvia. Nesse contexto, o trabalho no preparo de bebidas, comidas, roupas e tudo o mais que fosse ser consumido e utilizado nos festejos do Rosário certamente criava a necessidade de vínculos, relacionamentos, parcerias, diversos tipos de sociabilidade, enfim, entre os participantes da festa, antes mesmo de ela acontecer.

Para a coroação, os "súditos" iam buscar processionalmente seus reis e rainhas. No trajeto de ida e volta, o cortejo executava coreografias, jogos de habilidade e simulação de antigas guerras ocorridas na África, incluindo-se aí o choque de armas brancas (espadas). Após a cerimônia, o cortejo régio regressava às sedes, casas alugadas ou cedidas, onde havia festa com abundância de comida e bebida, música, cantorias e danças. ${ }^{16}$

Talvez por isso, o fim da coroação de reis na Irmandade tenha favorecido desdobramentos desse costume, por exemplo, em autos guerreiros que foram incorporando cantos e danças independentes daquela antiga manifestação cultural dos irmãos do Rosário. Nesse sentido, parece-me que o fim da festa de coroação de reis negros no âmbito da confraria do Rosário acabou contribuindo para ressaltar outros aspectos dessa manifestação cultural, dentre eles a encenação de antigos eventos ocorridos na África, como as guerras congo-angolesas. Eram as chamadas "apresentações de Congos".

\section{Autos de Rei Congo em praças e terrenos baldios de Fortaleza}

$\mathrm{Na}$ Fortaleza das últimas décadas do XIX, havia dois grandes grupos de Congos que se apresentavam em espaços já conhecidos pelos munícipes: os Congos de João Ribeiro, também chamado de "Pastoris Africanas" e que funcionavam num terreno baldio da Rua

\footnotetext{
16 CASCUDO, Luís da Câmara. Dicionário de folclore brasileiro. 11 ed. revista, atualizada e ilustrada. São Paulo: Global, 2002; MORAES FILHO, Mello. Festas e tradicõoes populares no Brasil. Brasília: Senado Federal, Conselho Editorial, 2002; TINHORÃO, José Ramos. Os sons dos negros no Brasil. Cantos, danças, folguedos: origens. São Paulo: Art Editora, 1988.
} 
Major Facundo, próximo à Praça do Livramento; e os Congos de João Gorgulho, que se apresentavam na Praça de Pelotas. ${ }^{17}$

Eram práticas festivas negras sobre as quais a polícia olhava com desconfiança associando-as à baderna e à desordem. Além disso, o preconceito contra práticas de raízes africanas, como os Congos, motivaram a iniciativa pessoal de alguns chefes de polícia (muitas vezes pressionados por parte da elite local), no sentido de reprimirem tais manifestações.

Foi o caso de Joaquim Pauleta de Bastos Oliveira. Nomeado para chefe de polícia ${ }^{18}$ do Ceará, em setembro de 1885, passou a exigir dos delegados e subdelegados da província um "profundo respeito a lei" a fim de garantirem o bem estar das respectivas localidades, a manutenção da ordem pública, a segurança individual da propriedade, prevenir e reprimir crimes. Sobre tudo isso o Dr. Pauleta exigia "pontualmente o conhecimento de qualquer ocurrencia com declaração das providencias tomadas". ${ }^{19}$

Assim, gradativamente, os Congos passaram a sofrer maior controle por parte da polícia. Entretanto, tal procedimento também gerava protestos, por exemplo, o publicado no jornal "Libertador", em 1889, reclamando do cerceamento aos Congos e a outros divertimentos. "No caracter de todas as prohibições policiaes, isso é de muito mau gosto", ${ }^{20}$

Observa-se que os Congos continuaram a se exibir na Capital, não apenas por ser uma prática arraigada na cultura da cidade, mas, também, por ser espaço alternativo de irmãos e ex-irmãos do Rosário que não mais podiam eleger e festejar seus reis negros naquela confraria. Veja-se como exemplo o caso do “preto Joaquim Xavier”, procurador da Irmandade do Rosário mas, também, embaixador da rainha Ginga em um dos autos de Rei Congo que se apresentavam em Fortaleza, como ilustra a citação que inicia esse artigo. ${ }^{21}$

Ao ser colocado como personagem de destaque nos Congos, Xavier representava uma possibilidade de o negro exercer suas práticas culturais em outro espaço que não o da Irmandade. Além disso, nota-se a capacidade de trânsito social desses sujeitos históricos.

17 BARrosO, Gustavo. Memórias de Gustavo Barroso. Edição em conjunto das obras: Coração de Menino, Liceu do Ceará e Consulado da China. 2. ed. Fortaleza: Governo do Estado do Ceará, 1989, p. 232; BARROSO, Gustavo. Ao som da viola. op. cit.; p. 170; sobre a denominação "Praça de Pelotas" (atualmente é a Praça Clóvis Beviláqua, em frente à Faculdade de Direito, pelo lado da Rua Senador Pompeu), ver: GIRÃO, Raimundo. Geografia estética de Fortaleza. Fortaleza: Imprensa Universitária do Ceará. 1959, p. 190.

18 APEC, Fundo Secretaria de Polícia do Ceará. Registro de oficios aos delegados. 16 set. 1885. Livro 264, fl. 188 v.

${ }_{19}$ APEC, Fundo Secretaria de Polícia do Ceará. Registro de oficios aos delegados. 7 out. 1885. Livro 336, fl. 10 v e 11.

${ }^{20}$ BPGMP, Núcleo de Microfilmagem. Jornal Libertador. Fortaleza, 14 jan. 1889, p. 2, rolo nº 227.

${ }^{21}$ Sobre o cargo de "procurador" da Irmandade, ver: BPGMP, Núcleo de Microfilmagem. Jornal Libertador. Fortaleza, 3 jan. 1890, p. 2, rolo n'. 201; sobre o papel de "embaixador" nos Congos, ver: NOGUEIRA, João. Fortaleza velha: crônicas. 2. ed. Fortaleza: Edições UFC/PMF, 1980, p. 128. 
Num momento Joaquim Xavier representava os interesses da Irmandade perante a Igreja ou ao Estado; noutro exercia um papel importante no auto de Rei Congo, não só como um dos atores principais, mas, provavelmente, também na organização do evento (preparo do local; autorização da polícia; divulgação em jornais; cobrança de ingressos).

Voltando à questão do controle, é preciso considerar que as posturas municipais da era republicana ratificaram certas políticas de repressão implementadas ainda nos tempos provinciais. Nessa tentativa de controle sobre divertimentos em locais públicos em Fortaleza, o extenso e polêmico código intendencial (posturas) de 1891 contribuiu para restringir os Congos a praças e terrenos cercados. ${ }^{22}$

Tal determinação acabou favorecendo a cobrança de ingressos e motivando uma maior espetaculariz̧ação dos autos de Rei Congo em Fortaleza, a exemplo daquele coordenado por João Ribeiro e que costumava se exibir num terreno baldio da Rua Major Facundo, nas proximidades da Praça do Carmo. Nesses moldes, outro Congo famoso da época foi o do negro João Gorgulho, açougueiro do Mercado Municipal, e que se apresentava na Praça de Pelotas. Gorgulho fazia o papel de embaixador da Rainha Ginga e herdara o comando desse Congo de um ex-escravo chamado Firmino que, por sua vez, representara por muitos anos o papel do Príncipe Sueno. ${ }^{23}$

Esses autos de Rei Congo eram anunciados em jornais onde se prometiam "ambiente familiar", "grande animação" e "apresentações marcantes" ou, ainda, contribuições para alguma obra de caráter social, muitas vezes na tentativa de promover o evento entre a elite fortalezense. Embora os anúncios trouxessem a expressão "Congos", estes eram, na verdade, espécies de encenações de eventos ocorridos na África dos séculos XVI e XVII, às quais se dará aqui a denominação de autos, seguindo a terminologia em geral adotada para se referir a uma forma teatral de enredo "popular", com danças, cantos e determinadas representações, no caso, fatos da história africana. ${ }^{24}$

Obviamente que, ao encenarem essas antigas histórias em terras brasileiras, os africanos e seus descendentes redimensionaram os fatos e provocaram, ao longo dos anos,

\footnotetext{
22 Várias críticas ao código de posturas de 1891, incluindo o cerceamento aos Congos, foram publicadas no Jornal Cearense nos dias 17, 18, 21, 22, de janeiro de 1891 (BPGMP, Núcleo de Microfilmes, rolo nº 41).

${ }^{23}$ BARROSO, Gustavo. Ao som da viola. op. cit., p. 170.

${ }^{24}$ Sobre definições e aplicações do termo "auto", ver: CARNEIRO, Edison. Folguedos tradicionais. 2. ed. Rio de Janeiro: FUNARTE, 1982; CASCUDO, Luís da Câmara. Dicionário de folclore brasileiro. 11 ed. revista, atualizada e ilustrada. São Paulo: Global, 2002; TINHORÃO, José Ramos. Os sons dos negros no Brasil. Cantos, danças, folguedos: origens. São Paulo: Art Editora, 1988; sobre esses aspectos históricos do Reino do Congo, particularmente a partir do contato com os europeus e, dentre estes, com os portugueses, que começaram a chegar às terras centro-ocidentais africanas ainda no século XV, ver: SILVA, Alberto da Costa e. A manilha e o libambo. A África e a escravidão, de 1500 a 1700. Rio de Janeiro: Nova Fronteira, 2002, p. 362; SOUZA, Marina de Mello e. Reis Negros no Brasil escravista. História da festa de coroação de Rei Congo. Belo Horizonte: EDUFMG, 2002, p. 306.
} 
certa mutabilidade nos personagens, danças e cantos presentes nos autos de Rei Congo, bem como, em outras manifestações culturais de raízes africanas (como os maracatus). É assim que, nessas encenações, o herdeiro (Suana) do trono congolês torna-se o Prinspo (Príncipe) Sueno; que Ginga (Rainha de Angola) chega a confraternizar com o manicongo (Rei do Congo) ou, ainda, que se cantam não apenas temas bélicos, mas, também, namoros, saudades, trabalho, tragédias e outras vivências dos negros no Brasil.

Por outro lado, parece que é justamente essa flexibilidade inerente ao processo (re)criador que permitia a perenidade dessa prática cultural. Nesse sentido é que os congos "revelam a fidelidade da gente negra às matrizes de uma cultura que se recusa a desaparecer". ${ }^{25}$

Em geral, o cenário dos autos de Rei Congo era um tablado coberto de bandeiras colocado no centro do terreno ou da praça. Em uma das extremidades colocava-se o trono real e na outra erguia-se um biombo coberto com panos sob os quais se ocultavam os personagens que deveriam entrar e sair de cena. À espera do rei, duas fileiras de soldadosdançarinos, usando camisas coloridas por baixo de um colete curto, saiotes armados à moda de bailarinas e enfeites de pena na cabeça. Dirigidos pelo Secretário, faziam evoluções coreográficas acompanhando com maracás o som da música tocada por instrumentistas sentados num banco fora do tablado.

Dentre os principais personagens estavam o Rei, que trazia uma coroa brilhante feita de papelão ou de flandres, usava manto aveludado vermelho, colete e calções coloridos e, na cintura, uma espada; o Príncipe, que trajava semelhante ao rei, faltando-lhe apenas a coroa; o Secretário, usando um grande chapéu de abas largas viradas para cima, ornados com pequenos espelhos que brilhavam à luz do acetileno ou mesmo de archotes e condeerios usados para clarear a noite. A indumentária do Embaixador da Rainha Ginga também incluía capa e espada. ${ }^{26}$

Geralmente o auto se iniciava com o Secretário brandindo uma espada e cantando entre as fileiras de seus comandados:

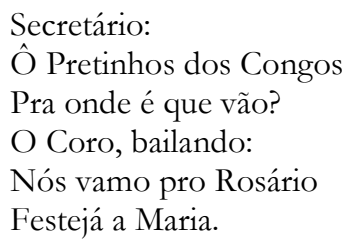

25 TINHORÃO, José Ramos. Os sons negros no Brasil. op. cit.,, p. 109.

26 As descrições do cenário e da indumentária dos personagens dos congos aparecem aqui a partir de: BARROSO, Barroso (Ao som da viola. ed. correta e aumentada. Rio de Janeiro: Departamento de Imprensa Nacional, 1949); AZEVEDO, Otacílio Fortalez̧a Descalça. 2. ed. Fortaleza: Imprensa Universitária da UFC, 1992; NOGUEIRA, João. Fortalez̧a velha: crônicas. 2. ed. Fortaleza: Edições UFC/PMF, 1980. 
Tem-se aqui uma referência à Igreja do Rosário de Fortaleza, sede da Irmandade de "Homens Pretos", onde se "festejava" Maria, mas também se elegiam e coroavam reis negros. Como visto, após a cerimônia, havia danças em frente à Igreja seguida de um cortejo pelas ruas da cidade, ampliando assim a "territorialidade" da festa. "Como isso fizesse juntar muita gente, interrompesse o trânsito e desse lugar a pilherias e conflitos, a polícia acabou confinando o auto em terrenos cercados ou murados". ${ }^{28}$

A despeito do impedimento legal do costume de coroar reis na Irmandade, o canto dos Congos aponta que o adro da Igreja do Rosário continuava sendo utilizado como espaço-referência no sentido de que ali estava parte de uma tradição cultural construída pelos negros em Fortaleza. Quanto ao "confinamento" do auto em terrenos cercados, era interessante para os Congos na medida em que tal procedimento possibilitava maior controle na cobrança de ingressos pagos pelo público que comparecia às apresentações.

Seguiam-se outros versos puxados pelo Secretário, dentre os quais um que ironizava a necessidade de licença policial para o funcionamento legal dos Congos.

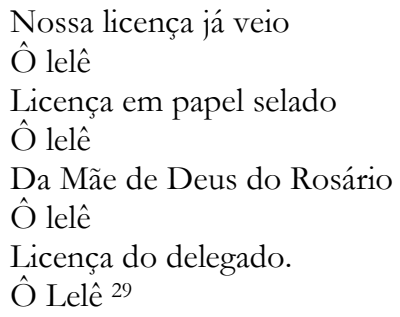

Outras quadras iam sendo cantadas, muitas vezes como instrumento de crítica social.

Os branquinhos vão dizendo

Que todo negro é ladrão.

Os branquinhos também roubam

Com sua pena na mão. ${ }^{30}$

\footnotetext{
${ }^{27}$ NOGUEIRA, João. Fortaleza velha. op. cit., p. 129-130; BARROSO, Gustavo. Ao som da viola. op. cit., p. 175.

${ }^{28}$ BARROSO, Gustavo. Ao som da viola. op. cit., p. 175.

${ }^{29}$ BARROSO, Gustavo. Ao som da viola. op. cit., p. 176.

${ }^{30}$ Essa quadra é registrada por vários escritores (romancistas e memorialistas) em fins do século XIX e início do XX. Cf. BARROSO, Gustavo. Ao som da viola. op. cit., p. 176. Há em várias publicações cearenses de fins do século XIX referências a "sambas" onde aparecem versos similares. Cf. PAIVA, Manoel de Oliveira. Dona Guidinha do Poço. 2. ed. São Paulo: Ática, 1981; MOTA, Leonardo. Cantadores. Poesia e linguagem do sertão cearense. 2. ed. Rio de Janeiro: Editora A Noite, 1953; CARVALHO, Rodrigues de. Cancioneiros do Norte. 3. ed. Rio de Janeiro: Instituto Nacional do Livro, 1967.
} 
Saindo do "biombo", que ficava num dos extremos do tablado, o monarca negro fazia sua aparição de modo imponente, precedido de alguns de seus "oficiais". Sobre esse momento de entrada em cena feita pelo Rei Congo, Otacílio de Azevedo comenta uma apresentação em que assistiu a João Gorgulho interpretar o "manicongo".

\begin{abstract}
Vestido na roupagem de seda colorida, cheia de fitas e arabescos, minúsculas lantejoulas, vidrilhos e brilhantes pedrarias, pavoneava-se e aparecia ao público com gestos de um verdadeiro rei. Seus valetes, de calça de cetim verde, justas ao corpo, colete violeta, clâmide vermelha caindo sobre os ombros e espadas de papelão dourado completavam a moldura daquela corte efêmera mas impressionante. Quando sentado no trono forrado de fofos de papel de seda salpicado de estrelas, tendo, à guisa de cetro, uma vara coberta de papel dourado, com um grande "S" na ponta, os pés metidos numas reiúnas de soldado, descansando num tablado, sobre um tapete de palha de carnaúba colorida - aí o espetáculo era mesmo empolgante e todos sentiam-se diminuídos por aquela grandeza. À cabeça, uma coroa de flandres pintada de cores diversas dava-lhe um ar diferente, afastando-o do comum dos mortais... ${ }^{31}$
\end{abstract}

$\mathrm{Na}$ presença do rei negro (Congo) seguiam-se danças acompanhadas por diversas variações musicais, e cantos eram reforçados com palavras de origem africana, o que de certa forma dava matiz negra à encenação. Por outro lado, eram justamente as múltiplas misturas de expressões africanas desfiguradas e de palavras portuguesas que davam uma identidade aos Congos fortalezenses. A possibilidade de reelaboração dos cantos permitia que essa "festa de negros" se mantivesse atualizada e atrativa para o público, sem no entanto, perder-se de suas raízes africanas.

Outrossim, muitos versos eram criados para agradar determinada parcela do público, que se constituía de representantes dos mais diversos segmentos sociais. A título de exemplo, veja-se o caso das quadras seguintes que denunciavam os "perigos" dos flertes entre os cadetes da Escola Militar do Ceará e as senhoritas da cidade.

\author{
Secretário: \\ Senhor Cadete \\ Da gola encarnada. \\ Coro: \\ Não namore a moça \\ Que ela é casada. \\ Secretário: \\ Senhor Cadete \\ Da gola azul. \\ Coro: \\ Não namore a moça
}

31 AZEVEDO, Otacílio de. Fortaleza Descalça. 2. ed. Fortaleza: Imprensa Universitária da UFC, 1992, p. 62-63. 
Que ela é do sul (...) ${ }^{32}$

Outras quadras iam sendo entoadas, sempre alternadas com os refrões do Coro. Embora fossem versos com as mais variadas inspirações, permitiam o revelar de uma cultura negra na festa. Finalizando o auto, cantava-se a vitória do exército da Rainha Ginga sobre o Rei Congo, cujo filho - "Príncipe Sueno" - acabava morto.

É importante destacar que os Congos cantavam uma África distante, muitas vezes adulterando nomes e fatos, não sendo isso erro de interpretação histórica, mas um indicativo de que era a capacidade dos negros de recriarem um passado que fazia essa cultura de raízes africanas existir do outro lado do Atlântico. Nesse sentido, os autos constituíam-se de permanências que lhes davam um toque de originalidade (nomes dos principais personagens, determinadas passagens da guerra congo-angolana, palavras africanas) e mudanças que tornavam o evento mais familiar aos espectadores (referências ao cotidiano na cidade de Fortaleza, a personalidades e a instituições locais).

Tudo isso, porém, agradava ao público que comparecia em número razoável. Ao mesmo tempo, os Congos tinham aí maiores possibilidades de serem vistos e, de certa forma, de afirmarem uma identidade cultural negra na cidade. Por outro lado, também existia o preconceito contra uma prática festiva de negros da qual participavam brancos (como observadores ou como atores) e que remetia a uma África considerada muitas vezes continente de costumes bárbaros.

Provavelmente reside aí a explicação para a apresentação dos Congos no período das festas natalinas. Assim como a coroação de reis negros na Irmandade do Rosário de Fortaleza aos poucos migrou do mês de outubro para o início de janeiro, os autos de Rei Congo passaram a ser apresentados em fins de dezembro até os primeiros dias do ano, particularmente o "Dia de Reis". Já em fins do século XIX, apareciam também na época do Carnaval.

Considerando que os Congos podiam absorver elementos simbólicos que lhes pareciam similares e que os costumes de matriz africana eram melhor aceitos se travestidos

\footnotetext{
32 BARrosO, Gustavo. Ao som da viola. op. cit, p. 186-188. Quanto à Escola Militar do Ceará, formava oficiais de carreira do Exército e funcionou em Fortaleza até o ano de 1897. Teve como sedes os prédios da atual $10^{a}$ Região Militar e do Colégio Militar de Fortaleza. Seus alunos - denominados "cadetes" - vinham de diversas partes do país e circulavam entre as mais variadas atividades culturais - públicas e privadas - na cidade. Nos seus uniformes de passeio, predominavam o vermelho (encarnado) e o azul, cores tradicionais do Exército Brasileiro. Cf. MARQUES, Janote Pires. O Casarão do Outeiro. Memórias e ilustrações. Fortaleza: ABC, 2007.
} 
de uma tradição europeia, aos poucos foi ocorrendo uma associação entre os reis congos e os reis magos, até porque um destes também era reconhecido como negro ou "escuro". 33

Certamente esse foi um processo antigo e lento, porém mais intenso nas últimas décadas do XIX, de forma que cada vez mais os Congos passavam a imitar o costume de se pedir óbulos no Dia de Reis, o que não deixava de ser mais uma tática ${ }^{34}$ de sobrevivência das práticas festivas negras. Assim, o constante cerceamento - particularmente o de caráter "romanizador", como já foi comentado - apenas motivara diversas reelaborações da cultura negra na cidade.

Nesse contexto de controle sobre os Congos, destaca-se a atuação da polícia. Embora os organizadores dessas práticas culturais divulgassem que a apresentação acontecia em ambiente "moralizado e seguro," certamente havia alterações, pela própria dinâmica da prática festiva que representava. Afinal, os Congos iam muito além de um simples "espetáculo"; eram o lugar da criação, da alegria, da bebida, do extravasar das emoções, da "conquista" dos espaços públicos.

Sob a ótica da polícia, no entanto, os Congos continuavam sendo vistos como propriciadores de ambiente potencial para "desordens". Era o que se registravam nos relatórios de polícia da época, como indicam os casos de Florencio Espindola Americano, profissão ferreiro, preso por "desordens num brinquedo de Congo na Rua da Boa Vista"; de Francisco Marques, ferreiro, preso por "embriaguez nos congos da Praça dos Coelhos"; de Jozé de Lima Uchôa, lavrador, preso por "embriaguez nos congos da Praça dos Coelhos". ${ }^{35}$

Ao que parece, as prisões geravam atitudes de desacato nos já alterados "brincantes", não apenas porque muitas vezes essas ações policiais eram arbitrárias e violentas, mas, também, por conta da bebida, que certamente deixava os "espíritos" mais agitados, como foi o caso de Francisco Gonçalo, tipógrafo, preso por “embriaguez e insolencia nos congos". ${ }^{36}$

É possível perceber que prisões incorriam sobre os frequentadores de origem mais simples, moradores de subúrbios e áreas pobres de Fortaleza, trabalhadores nas mais

\footnotetext{
${ }_{33}^{3}$ BPGMP, Núcleo de Microfilmagem. Jornal Cruzeiro do Norte. Fortaleza, 06 jan. 1913, p. 3, rolo nº 67.

${ }^{34}$ Uso a ideia de "tática" desenvolvida por Michel de Certeau, onde os mais fracos", não aceitavam o que era estabelecido nas fronteiras de um determinado lugar, buscando criar alternativas para sobreviverem e mesmo subverterem o sistema estabelecido pelos "mais fortes". Cf. CERTEAU, Michel de. A invenção do cotidiano: 1. artes do fazer. Petrópolis: Vozes, 1994, p. 100-101.

35 APEC, Fundo Governo do Estado do Ceará. Rol dos culpados. 12 dez. 1915. Caixa 02, Livro 07, p. 283; 18 dez. 1915. Caixa 02, Livro 07, p. 292.

36 APEC, Fundo Governo do Estado do Ceará. Rol dos culpados. 16 dez. 1915. Caixa 02, Livro 07, p. 290.
} 
diversas ocupações, que tinham nos Congos uma das poucas possibilidades de divertimentos e de sociabilidades. Por outro lado, parece que as detenções ocorriam no sentido de evitar que a festa se transformasse em tumulto. Assim, os "desordeiros" eram colocados em liberdade no dia seguinte à prisão. Em vista das constantes "alterações" ocorridas nos Congos, a polícia os proibiu de encenar utilizando espadas e facões, que passaram a ser confeccionados de madeira, uma "desonra" para os componentes do grupo. $^{37}$

Vale lembrar que esse olhar desconfiado em relação aos Congos não foi exclusivo das elites representantes de uma "República liberal", pouco simpáticas ao que fosse identificado com o regime político anterior. Ainda nos tempos do Império, essas práticas culturais já vinham sendo reprimidas pela polícia da Capital da província do Ceará.

\begin{abstract}
A SEMANA - Continua impassivel o firmamento, muito bom para os poetas que o preferem recamado de estrellas e com os azues d'Abril. Houve uns choviscos, d'entrudo, suppomos. Ao que parece a policia lá de cima prohibiu que deitassem chuvas para cá, do mesmo modo que a de cá impediu os congos e o bumba-meu-boi. No caracter de todas as prohibições policiaes, isso é de muito mau gosto. O delegado de policia do Firmamento é uma autoridade prevaricadora, violenta, empanturrada de ódios políticos. S.S., para nós é: tome sequidão, tome canícula; tome desgraça. E para os outros? Um belo escoar de primaveras, estios, invernos, outomnos, de que os livros estão cheios de bellas descripções. (...) com que agua se há de brincar entrudo esse anno. Com que, com qual? Ipso facto, non est agua in coelo nisi in terra. Fiat voluntas ambarum policia rum. Não haver agua para se brincar entrudo. Oh conspiração, oh concluio, oh pandilha. ${ }^{38}$
\end{abstract}

A transcrição ilustra um bem humorado protesto contra o controle sobre as festas promovido pelas autoridades em Fortaleza. Vê-se que os autos de Rei Congo começaram a sofrer crescentes restrições ainda no Ceará provincial. Talvez por buscarem espaços permitidos, já nas festas do Carnaval de 1887 apareciam alguns "Prisnpos Suenos" que desfilavam livremente nas ruas da Capital. ${ }^{39}$

Nas últimas décadas do século XIX, Fortaleza sofrera grandes transformações de ordem urbana que afetavam profundamente o cotidiano na cidade e alteravam os comportamentos de seus habitantes ${ }^{40}$. De certa forma, isso contribuía para desviar o heterogêneo público que assistia aos Congos. Enfrentando todas essas dificuldades, as "grandes" encenações de autos de Rei Congo em Fortaleza foram rareando no início do século XX, até porque dependiam em boa parte da iniciativa e da liderança pessoal de seus

${ }^{37}$ Cf. NOGUEIRA, João. Fortaleza velha. op. cit., p. 128.

38 BPGMP, Núcleo de Microfilmagem. Jornal Libertador. Fortaleza, 14 jan. 1889, p. 2, rolo nº 227.

${ }^{39}$ BPGMP, Núcleo de Microfilmagem. Jornal Libertador. Fortaleza, 23 fev. 1887, p. 2, rolo nº 202.

${ }^{40}$ Cf. PONTE, Sebastião Rogério. Fortaleza Belle Époque. In: SOUZA, Simone (Org.). Uma nova história do

Ceará, 3. ed. Fortaleza: Edições Demócrito Rocha, 2004, p. 165. 
diretores (João Gorgulho, João Ribeiro, Joaquim Xavier, Raymundo Evangelista e outros) para serem montados. Mas esses homens não eram eternos.

Porém, essa e outras práticas festivas negras estavam arraigadas na cultura fortalezense, de forma que, tanto no ciclo das festas natalinas, como no período carnavalesco, os Congos continuaram existindo, ainda que em pequenos grupos que constantemente reelaboravam uma cultura negra a partir de suas experiências sociais vividas cotidianamente.

\section{Considerações finais}

Ante o exposto, é possível perceber que vários fatores - o conservadorismo católico, a "romanização", a atuação das Conferências Vicentinas, o preconceito contra manifestações festivas de matriz africana, a ambição em tomar o patrimônio da Irmandade que se valorizava com o crescimento urbano de Fortaleza, um Estado republicano pouco interessado no negro - contribuíram para o esvaziamento da Irmandade do Rosário enquanto espaço para a cultura e a sociabilidade negra em Fortaleza.

Apesar de tudo, persistia uma cultura negra festiva na cidade, onde novos espaços foram (re)criados ou ampliados de forma que muitos irmãos e ex-irmãos migraram de vez para atividades culturais, como os Congos, que ocorriam em praças e terrenos baldios, encenando antigas guerras congo-angolanas.

Ao mesmo tempo, os Congos se permitiam ao diálogo com outras práticas festivas negras existentes na cidade. Era o caso dos maracatus, que traziam reis negros em seu cortejo e desfilavam solenemene pela cidade, tradição que permanece até os dias atuais em Fortaleza. Mas essa, já é uma outra história... 